\title{
The human pressure on the middle Vistula River wildlife: the number and distribution of people and their activity on the river during the breeding season of birds*
}

\author{
Presja człowieka na przyrodę środkowej Wisły: liczba i rozmieszczenie ludzi oraz formy \\ ich aktywności na rzece w okresie rozrodu ptaków
}

\section{Dariusz Bukaciński, Monika Bukacińska, Ewelina Mastalerz}

Institute of Ecology and Bioethics, Cardinal Stefan Wyszyński University in Warsaw, Poland

ORCID: DB https://orcid.org/0000-0003-0163-2950; MB https://orcid.org/0000-0002-4526-3141 • d.bukacinski@uksw.edu.pl

\begin{abstract}
The study aimed to determine the distribution, numbers, and forms of human activity on the banks and in the riverbed of the middle part of the Vistula River. This section of the river is the most valuable for nature and is located between Puławy and the mouth of the Pilica River (km 373-548 of the navigation route). Censuses were conducted in May-June 2014 and 2015, the breeding season of the key species of the riverbed avifauna. The presence and different forms of human activity were recorded, including fishing, camping, water tourism, hiking, motorized tourism, and grazing animals. The frequent presence of people on the Vistula River was much greater in June than in May. In both months, the most popular form of spending time by humans in the riverbed was fishing. While in areas less valuable for birds, fishing strongly dominated, on parts of the river with key breeding habitats for birds, more aggressive forms of recreation, camping and motorized tourism (quads, motorcycles, off-road vehicles), were reported as often or even more frequently. The increasing popularity of these forms of recreation is a very serious threat to the fauna. They not only disturb the breeding birds but also physically destroy breeding habitats and nests with eggs and increase the mortality of chicks of gulls, terns, and other waders.
\end{abstract}

Keywords: Middle Vistula Valley, Natura 2000, human pressure, birds of Vistula River, the impact of tourism and recreation, the threats to gulls and terns on the river

Streszczenie: Celem pracy było określenie rozmieszczenia, liczby i form aktywności ludzi na brzegach i w korycie najcenniejszego pod względem przyrodniczym, środkowego odcinka Wisły między Puławami i ujściem Pilicy (km 373-548 szlaku żeglugowego). Kontrole prowadzono w okresie maj-czerwiec 2014-2015 roku, kiedy do rozrodu przystępowały kluczowe gatunki ptaków, tworzących zespół awifauny koryta rzeki. Notowano obecność i formę aktywności ludzi wyróżniając: wędkarstwo, biwaki, turystykę wodną, turystykę pieszą, turystykę zmotoryzowaną oraz wypas zwierząt hodowlanych. Stwierdzono częstą obecność ludzi na Wiśle, bardziej masową w czerwcu niż w maju. W obu miesiącach najbardziej popularną formą spędzania czasu przez ludzi w korycie rzeki było wędkarstwo. Podczas gdy na terenach mniej cennych dla ptaków zdecydowanie dominowało łowienie ryb, na fragmentach rzeki z kluczowymi siedliskami lęgowymi dla ptaków równie często lub częściej notowano zdecydowanie bardziej agresywne dla przyrody formy rekreacji: biwaki i turystykę zmotoryzowaną (quady, motory, samochody terenowe). Wzrastająca popularność tych form rekreacji stanowi bardzo poważne zagrożenie dla świata przyrody ożywionej. Ich efektem jest nie tylko niepokojenie ptaków wyprowadzających lęgi, ale też fizyczne niszczenia siedlisk lęgowych, gniazd z jajami oraz zwiększona śmiertelność piskląt mew, rybitw i innych ptaków siewkowych.

Słowa kluczowe: Dolina Środkowej Wisły, Natura 2000, presja człowieka, awifauna Wisły, wpływ turystyki i rekreacji, zagrożenia dla mew i rybitw na rzece

\footnotetext{
"This article was originally published in Polish as Bukaciński, Dariusz, Monika Bukacińska, i Ewelina Mastalerz. 2015. „Presja człowieka na przyrodę środkowej Wisły: liczba i rozmieszczenie ludzi oraz formy ich aktywności na rzece w okresie rozrodu ptaków." Studia Ecologiae et Bioethicae 13(4): 143-178. The translation of the article into English was financed by the Ministry of Science and Higher Education of the Republic of Poland as part of the activities promoting science - Decision No. 676/P-DUN/2019 of 2 April 2019. Translation made by GROY Translations.
} 


\section{Introduction}

Extremely fertile floodplain soils, the possibility of using watercourses for transport and communication purposes, and the constant availability of fresh water and fish are just some of the important reasons why, starting from the Palaeolithic period, river valleys function as "spatio-temporal cultural and civilization sequences", becoming a place of increased settlement and major anthropogenic transformations (Andrejczuk 2007). As a result, the natural landscape of a large braided river with riparian forests in the valley, steep banks, a wide riverbed, numerous meanders, islands and sandbanks in the current, and the characteristic group of birds inhabiting them, is nowadays extremely rare in Europe (Imboden 1987; Reichholf 1987; Tomiałojć and Dyrcz 1993; Chylarecki et al. 1995).

One of such unique rivers is the Vistula. It remains the last large European watercourse, which has retained its almost original character on a large section. In many places of the riverbed, we can observe both low, dynamically changing sandbanks and higher islands at various stages of plant succession. On the banks, there are sandy slopes, fragments of riparian forests, oxbow lakes and flooded meadows, which are a shelter for many species of birds (Chylarecki et al. 1995; Dombrowski et al. 1998; Bukaciński 2010). Despite the anthropogenic transformations of the valley, regulation and construction of upstream or downstream barrages in the riverbed, the Vistula continues to be a key element of the natural system of the country, being an ecological corridor and a breeding habitat for many animals, including those endangered with extinction (Chylarecki et al. 1995; Liro et al. 1995; Sawicki 2003; Bukaciński 2010; Bukaciński and Bukacińska 2015a). Unlike other large canalised rivers in Europe, it still has undeniable cultural and landscape values (Andrejczuk 2007; Angiel 2007; Angiel and Bukaciński 2015). The most valuable is the middle course of the river, where on the more than 250-kilometre-long fragment of the valley the "Middle Vistula Valley" Special Bird Protection area was established (Chylarecki and Sawicki 2003; Bukaciński 2010). One of the human activities that have been entering many places in the middle course of the river for decades, both on the banks and the islands, is the livestock grazing (Bukaciński and Bukacińska 1995; Bukacińska and Bukaciński 2004a, b, c). The beauty of the landscape of this area and a trend for close contact with nature make the "Middle Vistula Valley" also increasingly exposed to human pressure in the last decade, often associated with new and more aggressive forms of tourism, the effect of which is the physical destruction of habitats and noise that disrupts and often prevents reproduction, especially for birds and mammals (Bukaciński and Bukacińska 2001; Bukaciński, Bukacińska, and Buczyński 2011, 2013).

The study aimed to determine the distribution, size and forms of human activity on the banks and in the riverbed of the most valuable in terms of nature, the middle section of the Vistula in the spring-summer period (May-June), in the most critical period of breeding birds. Analysis of the results of the observed human pressure in the context of the location of key Vistula breeding sites of rare and endangered Charadriiformes bird species (mew gull Larus canus, mediterranean gull Ichthyaetus melanocephalus, little tern Sternula albifrons, common tern Sterna hirundo, ringed plover Charadrius hiaticula and little ringed plover Charadrius dubius) will allow assessing the degree of the potential threat of gulls, terns and plovers to lose their breeding grounds and/or to leave the breeding grounds as a direct or indirect result of human presence.

\section{Study area, material and methods}

The research was conducted in June 2014, May and June 2015. It covered the southern, 85-km section of the "Middle Vistula Valley" Special Bird Protection Area - PLB 14004 (Chylarecki and Sawicki 2003), between Puławy and the mouth of Pilica $(\mathrm{km}$ 373-458 of the navigation route). This 
area is at the same time created within the NATURA 2000 network, an international nature refuge of the same name, with IBA number 083 (Bukaciński 2010).

The assessment of the distribution, size and type of human activity was carried out based on the common monitoring method recommended for the avifauna of the riverbed (Bukaciński and Bukacińska 2015b, c; Bukaciński, Bukacińska, and Zieliński 2015). It involves one or two censuses (boat trips), combined with a foot inspection of all major islands and sandbanks. When assessing human pressure, all signs of presence were recorded, and all people on the islands and both banks of the river were counted (up to 20-30 m from the coast). A total of 3 inspections were carried out during the spring-summer period 20142015: one in 2014, the first decade of June, and two in 2015: the second decade of May and the first decade of June 2015. Inspection dates were set at optimal dates, taking into account the reproductive phenology of the key bird species of the riverbed complex (gulls, terns, plovers, goosander Mergus merganser, sand martin Riparia riparia, common kingfisher Alcedo atthis) and the dynamics of the river flow. The high and long-lasting water rise in the second half of May 2014 made it impossible to carry out a fully representative (i.e. typical for average water level conditions) May inspection. The river was driven by a pontoon boat with an outboard engine.

While compiling the results, six types of human activity on the river were distinguished: (1) fishing, recorded equally often on the banks and in the riverbed on the islands, including people fishing with a fishing rod or with the use of nets, landing nets, etc., (2) stationary "family" camping found more often on islands than on the riverbanks, including bonfires and fresh traces of them, tents, campsites, caravans, shelters, etc., (3) water tourism, where windsurfing, kayaks, boats, sailboats water scooters, tourist ships, etc. were included, (4) hiking, including walkers, cyclists, sunbathing and resting people, almost exclusively on islands, peninsulas, spurs, hori- zontal dams, etc.), (5) mechanized tourism on islands, shoals and peninsulas including quads, motorbikes, mopeds and off-road vehicles and (6) grazing livestock on the islands (horses, cows, sheep and goats) The following were considered as measures of human pressure: the number of people, the number of places with their presence and the frequency of the above-mentioned activities at each kilometre of the river. Within the 85-kilometre-long monitored section of the river, fragments of the river were distinguished in (a) the most valuable natural part of the river (further in the text presented with the OBC symbol) covering 30 kilometres of the river between the kilometres: 382-386, 391-395, 399-404, $410-419,440-445$ and 454-457. The riverbed in these places is wide, winding, with numerous islands at various stages of plant succession and sandbanks and steep banks providing breeding habitats for all key species of the avifauna of the riverbed;(b) naturally valuable (hereinafter referred to as $\mathrm{OC}$ ), covering 39 river kilometres between km: 379-382, 386-391, 395-399, 404-410, 419-420, 429-440 and 495-454. These places differ from the above-mentioned ones in a greater proportion of older islands, compared to low sandy shoals, as a result of which they were inhabited by gulls, terns and plovers which are less numerous than in the areas identified as the most valuable and (c) the least valuable (hereinafter referred to as OMCs) covering 16 kilometres of the river between $\mathrm{km}$ 373-379, 420-429 and 457-458. These are urban sections of the river (Puławy) and those at the level of Kozienice Power Plant and the mouth of Pilica River. They are more regulated, usually without islands or shoals in the current, with concrete banks, bank bands and/or spurs reaching into the riverbed. The basis for assessing the importance of kilometres of the river bed as breeding habitats for avifauna was the abundance and distribution of key bird species of the river bed in 1990-2015 on the fragment of the river covered by this monitoring (Bukaciński and Bukacińska 1994; Bukaciński et al. 1994; Keller et 
al. 1999; Kot et al. 2009; Bukaciński et al., unpublished).

Standard statistical description tests were used. The differences between the means were compared using one-way ANOVA and Student's t-test, the significance of differences between the frequency distributions was checked using the chi-square test (Zar 1984; Łomnicki 2010).

\section{Results}

\subsection{Number and distribution of people on the river}

Monitoring of people in the Vistula riverbed between Puławy and the mouth of Pilica ( $\mathrm{km} \mathrm{373-458} \mathrm{of} \mathrm{the} \mathrm{navigation}$ route) in the spring-summer period in the years 2014-2015 showed increased and varied human activity in the area. During the censuses in June, a total of 242 people were found on both banks and islands in both years, which amounted to an average of more than 2.8 people per running $\mathrm{km}$ of river. The majority (over 65\%) were in the riverbed (islands, peninsulas). In May 2015 , the number of people relaxing in the Vistula riverbed was much smaller. At that time 122 people were recorded (an average of 1.4 persons per current $\mathrm{km}$ ). About half of them (ca. 47\%) was on the river banks, the rest (approx. 53\%) on islands and peninsulas (Annex 1-3). The distribution of people on the river differed between June 2014 and June 2015, but was always uneven. The places of greatest concentration were more or less constant in both years. In the northern part of IBA, most people were observed between Puławy and Gołąb (375-382 km), in the central part - between Wróble and Antoniówka (415-427 $\mathrm{km})$, and in the southern part - between Podwierzbie and Ruda Tarnowska (437$442 \mathrm{~km}$ ) (Annex 1-3).

The density of people on OMC was similar to that noted in the OBC sites (ANOVA, $\mathrm{p}>0.05)$. During the censuses in June, it varied in the range of $3.0 \pm 2.1$ individuals/ per running $\mathrm{km}$ of the river (OMC sites, the year 2015) and 3.8 \pm 2.9 ind./km (OMC sites, the year 2014) (Table 1). In May 2015 , these differences were already great-
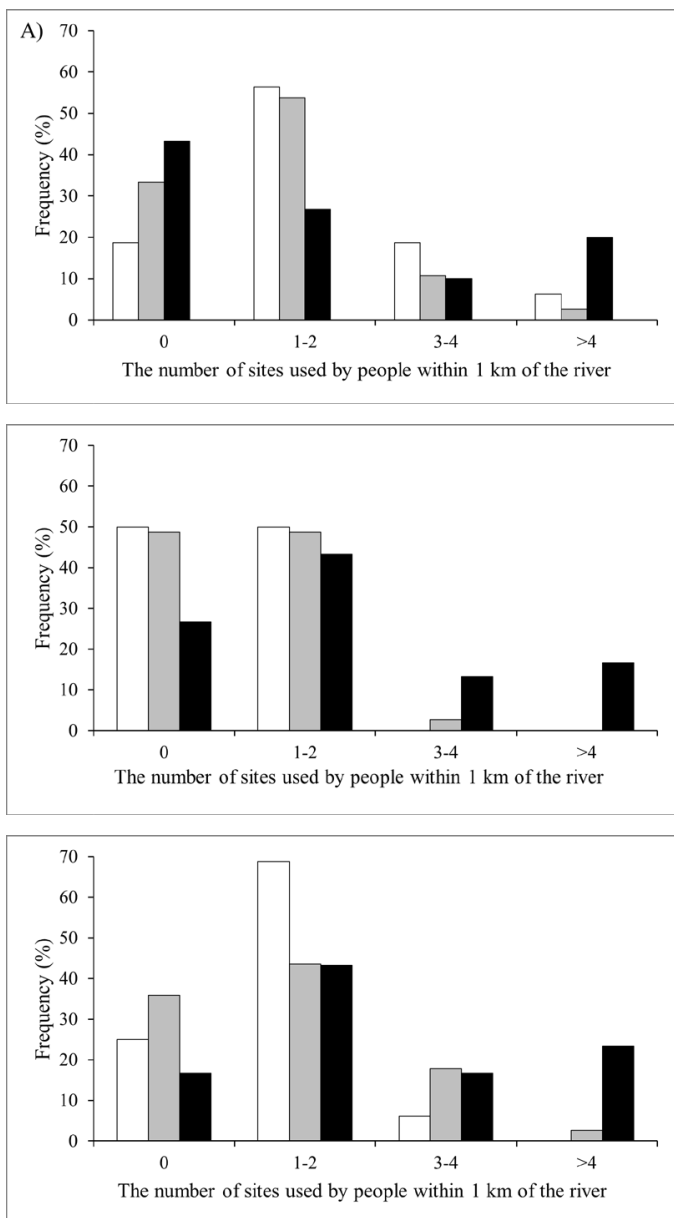

Fig. 1. The presence of people on the banks and in the Vistula riverbed between Puławy and the mouth of Pilica (373-458 $\mathrm{km}$ of the navigation route in (A) June 2014, (B) May 2015 and $(C)$ June 2015. Indicated values as the number of sites used by people for all listed activities in total. On the OY axis, the frequency was calculated as a percentage of 1-kilometer sections with a given number of places where people were found. Blank bars - OMC area $(\mathrm{N}=16)$, grey bars - OC area $(\mathrm{N}=39)$, black bars - OBC area $(\mathrm{N}=30)$. $\mathrm{N}$ - the number of 1-kilometer sections of the river.

er (1.1 \pm 1.1 ind./ $/ \mathrm{km}$ versus $1.6 \pm 1.2$ ind./ $\mathrm{km}$ for OMC and OBC respectively) but still statistically insignificant (Table 1 ). At $\mathrm{OC}$, the average number of people per one running kilometre of the river was usually similar to that observed in the other two areas (OMC and OBC). Only in June 2014, significantly fewer people were recorded 
Table 1. The number of fishermen and other people staying on the banks and in the riverbed the Vistula between Puławy and the mouth of Pilica per one running kilometre of a river of a different class of natural value (average number of people $\pm S D$ ) in the springsummer period of 2014-2015. $\mathrm{N}$ - number of one-kilometre long river sections with a given class of natural value (description of symbols in the chapter "Study area, material and methods" and in Annexes 1 and 4); F - values of one-way ANOVA; $p$ - the significance of differences; NS - non-significant differences $(p>0.05)$, ***, **** - significance of differences, Student's t-test respectively $\mathrm{p}<0.05, \mathrm{p}<0.01, \mathrm{p}<0.001$.

\begin{tabular}{|c|c|c|c|c|c|}
\hline \multirow{3}{*}{$\begin{array}{l}\text { Year and } \\
\text { month }\end{array}$} & & \multicolumn{3}{|c|}{$\begin{array}{c}\text { Environmental value } \\
\text { (importance of habitats for birds) }\end{array}$} & \multirow{3}{*}{$\begin{array}{l}\text { ANOVA (between } \\
\text { areas) }\end{array}$} \\
\hline & & OMC & OC & $\mathrm{OBC}$ & \\
\hline & & $N=16$ & $\mathrm{~N}=39$ & $\mathrm{~N}=30$ & \\
\hline \multirow[t]{3}{*}{$\begin{array}{l}2014 \\
\text { June }\end{array}$} & fishing & $1.8 \pm 1.6$ & $0.9 \pm 1.2$ & $\ulcorner 0.8 \pm 0.9$ & $\begin{array}{c}\mathrm{F}_{2.82}=4.04 \\
\mathrm{p}<0.02\end{array}$ \\
\hline & other activities & $1.9 \pm 1.9$ & $0.9 \pm 0.9$ & $\llcorner 2.9 \pm 2.4$ & $\begin{array}{c}\mathrm{F}_{2.82}=6.25 \\
\mathrm{p}<0.01\end{array}$ \\
\hline & total & $3.8 \pm 2.9$ & $1.8 \pm 1.5$ & $3.7 \pm 2.3$ & $\begin{array}{c}F_{2.82}=4.18 \\
\quad p<0.02\end{array}$ \\
\hline \multirow{3}{*}{$\begin{array}{l}2015 \\
\text { May }\end{array}$} & fishing & $\Gamma 0.8 \pm 1.0$ & $0.9 \pm 1.2$ & $\Gamma 0.4 \pm 0.6$ & NS \\
\hline & other activities & $\llcorner 0.3 \pm 0.9$ & $0.6 \pm 0.8$ & $\llcorner 1.1 \pm 0.9$ & $\begin{array}{c}\mathrm{F}_{2.82}=4.28 \\
\mathrm{p}<0.02\end{array}$ \\
\hline & total & $1.1 \pm 1.1$ & $1.5 \pm 1.5$ & $1.6 \pm 1.2$ & $N S$ \\
\hline \multirow{3}{*}{$\begin{array}{l}2015 \\
\text { June }\end{array}$} & fishing & $\ulcorner 1.9 \pm 1.1$ & $\ulcorner 0.9 \pm 1.0$ & $\ulcorner 1.2 \pm 0.9$ & $\mathrm{F}_{2.82}=4.46$ \\
\hline & other activities & $\left\llcorner^{* * *} 1.0 \pm 1.0\right.$ & $\left\llcorner_{1.7 \pm 1.6}\right.$ & $L^{* * * * *} 1.9 \pm 1.2$ & $\begin{array}{c}\mathrm{p}<0.02 \\
\mathrm{~F}_{2.82}=3.41 \\
\mathrm{p}<0.05\end{array}$ \\
\hline & total & $3.0 \pm 2.1$ & $2.6 \pm 2.7$ & $3.1 \pm 1.2$ & $N S$ \\
\hline \multirow{3}{*}{$\begin{array}{l}\text { ANOVA } \\
\text { (between } \\
\text { years) }\end{array}$} & fishing & $\begin{array}{c}\mathrm{F}_{2.45}=3.91 \\
\mathrm{p}=0.05\end{array}$ & $N S$ & $\begin{array}{c}\mathrm{F}_{2.87}=7.27 \\
\mathrm{p}<0.01\end{array}$ & \\
\hline & other activities & $\begin{array}{c}\mathrm{F}_{2.45}=5.10 \\
\mathrm{p}<0.01\end{array}$ & $\begin{array}{c}\mathrm{F}_{2.114}=6.90 \\
\mathrm{p}<0.01\end{array}$ & $\begin{array}{c}\mathrm{F}_{2.87}=4.31 \\
\mathrm{p}<0.05\end{array}$ & \\
\hline & total & $\begin{array}{l}\mathrm{F}_{2.45_{5}}=5.91 \\
\mathrm{p}<0.01\end{array}$ & $\begin{array}{c}\mathrm{F}_{2.114}=3.92 \\
\mathrm{p}<0.02\end{array}$ & $\begin{array}{c}\mathrm{F}_{2.87}=4.66 \\
\mathrm{p}<0.05\end{array}$ & \\
\hline
\end{tabular}

there than in other places $(1.8 \pm 1.5$ ind./ $\mathrm{km} ; \mathrm{F}_{2,82}=4.18, \mathrm{p}<0.02$, Table 1 ).

Despite similar densities, the distribution of people on the river changed significantly depending on the natural value of the river valley (between $X^{2}=11.97$ (6), $\mathrm{p}=0.06$ in June 2014 and $\mathrm{X}^{2}=16.19$ (6), $\mathrm{p}=0.01$ in May 2015) (Fig. 1). Regardless of the date of the censuses, there were usually no people at all at OMC (20-50\% of the sections, depending on the date of the censuses), or they may have appeared at one or two sites of the one-kilometer section (50-68.8\% of the sections) (Fig. 1).
The number of people on OBC was much more evenly distributed. Depending on the date of censuses, no people were observed in $16.7-43.3 \%$ of such one-kilometer sections, in $26.7-43.3 \%$ of the sections we have observed people in 1-2 sites, in the further $10.0-16.7 \%$ of the sections in 3 - 4 sites, and in $16.7-23.3 \%$ of the sections in more than four sites (Fig. 1). The distribution of people in the $\mathrm{OC}$ was less concentrated than on the least attractive to birds but at the same time it was less evenly distributed than in the places that are the most valuable in terms of nature (Fig. 1). 


\subsection{Forms of activity of people staying in the Middle Vistula Valley}

The distribution of places of distinguished human activity on the banks and in the Vistula riverbed between Puławy and the mouth of Pilica in spring and summer of 2014-2015 is presented in detail in Annex 4-6. During the censuses in May 2015, human presence was recorded at 78 sites $(0.92$ sites/running $\mathrm{km}$ of the river on average), and during the census in June, depending on the year, at 133 and 140 sites (1.56-1.64 sites/ $\mathrm{km}$ on average) (Annex 4-6).

Considering the whole controlled fragment of the river, the frequency of occurrence of particular forms of human activity on the middle Vistula did not differ significantly between successive censuses $\left(x^{2}\right.$ $=15.97$ (10), $\mathrm{p}>0.05)$. Most often we met people fishing. Most often, they were fishermen, less often people on boats fishing with nets. They were present, depending on the date of censuses, in $32.3-42.9 \%$ of places, and at the same time constituted the largest fraction of people (depend- ing on the date of censuses, between 37.2 and $49.2 \%$ of all people met on the river). However, the distribution of this form of spending time was not even. It was usually found more frequently in $\mathrm{OMC}$ than in $\mathrm{OC}$ and/or OBC (ANOVA, $\mathrm{F}_{2.82}=3.25$, $\mathrm{p}<0.05$ and $\mathrm{F}_{2.82}=10.88, \mathrm{p}<<0.001$, for June 2014 and 2015 respectively, Table 2). The number of fishermen encountered was always clearly higher in OMC than in places more valuable in terms of nature (OC and $\mathrm{OBC}$ ) (usually twice or more), and the differences were greater during the June censuses (ANOVA, $\mathrm{F}_{2.82}=4.04$ and $\mathrm{F}_{2.82}=4.46$, $\mathrm{p}<0.02$, for June 2014 and 2015 respectively, Table 1). It is worth noting that at OMC fishing was the basic and most frequently recorded form of activity in the river valley, taking into account the number of people (Student's t-test, $\mathrm{t}=2.09(30), \mathrm{p}<0.05$ and $\mathrm{t}$ $=2.58$ (30), $\mathrm{p}<0.01$, for May and June 2015 respectively, Table 1 ) as well as the number of places (Table 2). This was different at OC and $\mathrm{OBC}$, where activities other than fishing were much more common (Table 2),

Table 2. Number of places with distinguished activities of people on the banks and in the Vistula riverbed between Puławy and the mouth of Pilica per one running kilometre of a river of a different class of natural value (average number of places \pm SD) for the spring-summer period of 2014-2015. W - fishing, B - camping (bonfires, tents, campers, etc.), TW - water tourism (all vessels, including windsurfing and jet skis), TL - hiking on islands and peninsulas (people walking, sunbathing, playing, swimming, etc.), Q - offroad vehicles on islands and peninsulas (quads, motorcycles, off-road vehicles, etc.), ZW - grazing animals on islands (cows, horses, sheep, goats).

\begin{tabular}{|c|c|c|c|c|c|}
\hline \multirow{2}{*}{$\begin{array}{l}\text { Census } \\
\text { date }\end{array}$} & \multirow{2}{*}{$\begin{array}{l}\text { Type of } \\
\text { activity }\end{array}$} & \multicolumn{3}{|c|}{ Nature value of the area for birds } & \multirow{2}{*}{$\begin{array}{c}\text { ANOVA } \\
\text { (between areas) }\end{array}$} \\
\hline & & $\begin{array}{l}\text { OMC } \\
\mathrm{N}=16\end{array}$ & $\begin{array}{c}\mathrm{OC} \\
\mathrm{N}=39\end{array}$ & $\begin{array}{l}\mathrm{OBC} \\
\mathrm{N}=30\end{array}$ & \\
\hline \multirow{7}{*}{$\begin{array}{l}2014 \\
\text { June }\end{array}$} & W & $0.8 \pm 0.6$ & $0.5 \pm 0.6$ & $0.3 \pm 0.4$ & $\begin{array}{c}\mathrm{F}_{2.82}=3.25 \\
\mathrm{p}<0.05\end{array}$ \\
\hline & B & $0.4 \pm 0.5$ & $0.2 \pm 0.2$ & $0.4 \pm 0.6$ & $\begin{array}{c}\mathrm{F}_{2.82}=3.60 \\
\mathrm{p}<0.05\end{array}$ \\
\hline & TW & $0.1 \pm 0.2$ & $0.3 \pm 0.4$ & $0.3 \pm 0.3$ & NS \\
\hline & $\mathrm{TL}$ & $0.3 \pm 0.3$ & $0.2 \pm 0.3$ & $0.6 \pm 0.4$ & $\begin{array}{c}\mathrm{F}_{2.82}=4.69 \\
\mathrm{p}<0.02\end{array}$ \\
\hline & Q & $0.05 \pm 0.1$ & $0.03 \pm 0.05$ & $0.11 \pm 0.12$ & $\begin{array}{c}\mathrm{F}_{2.82}=2.79 \\
\mathrm{p}=0.067\end{array}$ \\
\hline & ZW & $0.0 \pm 0.0$ & $0.1 \pm 0.1$ & $0.14 \pm 0.1$ & $\begin{array}{c}\mathrm{F}_{2.82}=2.94 \\
\mathrm{p}=0.058\end{array}$ \\
\hline & total & $1.7 \pm 1.1$ & $1.3 \pm 1.0$ & $2.0 \pm 1.5$ & $\begin{array}{c}F_{2.82}=3.15 \\
p<0.05\end{array}$ \\
\hline
\end{tabular}




\begin{tabular}{|c|c|c|c|c|c|}
\hline 2015 & W & $0.4 \pm 0.4$ & $0.3 \pm 0.3$ & $0.3 \pm 0.4$ & NS \\
\hline \multirow[t]{6}{*}{ May } & B & $0.1 \pm 0.1$ & $0.2 \pm 0.2$ & $0.3 \pm 0.3$ & $\begin{array}{c}\mathrm{F}_{2.82}=3.65 \\
\mathrm{p}<0.05\end{array}$ \\
\hline & TW & $0.1 \pm 0.2$ & $0.1 \pm 0.2$ & $0.2 \pm 0.2$ & NS \\
\hline & $\mathrm{TL}$ & $0.0 \pm 0.0$ & $0.1 \pm 0.2$ & $0.1 \pm 0.2$ & NS \\
\hline & Q & $0.0 \pm 0.0$ & $0.1 \pm 0.1$ & $0.2 \pm 0.1$ & $\begin{array}{c}\mathrm{F}_{2.82}=4.48 \\
\mathrm{p}<0.02\end{array}$ \\
\hline & ZW & $0.0 \pm 0.0$ & $0.1 \pm 0.1$ & $0.2 \pm 0.11$ & $\begin{array}{c}\mathrm{F}_{2.82}=6.13 \\
\mathrm{p}<0.005\end{array}$ \\
\hline & total & $0.6 \pm 0.3$ & $0.8 \pm 0.1$ & $1.3 \pm 0.6$ & $\begin{array}{c}F_{2.82}=5.01 \\
p<0.01\end{array}$ \\
\hline \multirow[t]{7}{*}{$\begin{array}{l}2015 \\
\text { June }\end{array}$} & W & $0.8 \pm 0.7$ & $0.4 \pm 0.5$ & $1.1 \pm 0.5$ & $\begin{array}{c}\mathrm{F}_{2.82}=10.88 \\
\mathrm{p}<<0.001\end{array}$ \\
\hline & B & $0.2 \pm 0.3$ & $0.2 \pm 0.3$ & $0.4 \pm 0.4$ & NS \\
\hline & TW & $0.04 \pm 0.1$ & $0.1 \pm 0.1$ & $0.2 \pm 0.3$ & $\begin{array}{c}\mathrm{F}_{2.82}=3.62 \\
\mathrm{p}<0.05\end{array}$ \\
\hline & $\mathrm{TL}$ & $0.1 \pm 0.2$ & $0.3 \pm 0.4$ & $0.4 \pm 0.5$ & NS \\
\hline & Q & $0.05 \pm 0.1$ & $0.1 \pm 0.2$ & $0.2 \pm 0.2$ & $\begin{array}{c}\mathrm{F}_{2.82}=3.05 \\
\mathrm{p}=0.06\end{array}$ \\
\hline & ZW & $0.0 \pm 0.0$ & $0.1 \pm 0.1$ & $0.3 \pm 0.3$ & $\begin{array}{c}\mathrm{F}_{2.82}=6.88 \\
\mathrm{p}<0.001\end{array}$ \\
\hline & total & $1.2 \pm 0.8$ & $1.2 \pm 0.9$ & $2.5 \pm 1.1$ & $\begin{array}{c}\mathrm{F}_{2.82}=8.54 \\
\mathrm{p}<<0.001\end{array}$ \\
\hline \multirow{7}{*}{$\begin{array}{l}\text { ANOVA } \\
\text { (between } \\
\text { years) }\end{array}$} & W & $\begin{array}{c}\mathrm{F}_{2.45}=4.06 \\
\mathrm{p}<0.05\end{array}$ & NS & $\begin{array}{c}\mathrm{F}_{2.87}=18.79 \\
\mathrm{p}<<0.001\end{array}$ & \\
\hline & B & $\begin{array}{c}\mathrm{F}_{2.45}=6.69 \\
\mathrm{p}<0.02\end{array}$ & NS & NS & \\
\hline & TW & NS & $\begin{array}{c}\mathrm{F}_{2.114}=5.29 \\
\mathrm{p}<0.01\end{array}$ & NS & \\
\hline & $\mathrm{TL}$ & NS & $\mathrm{F}_{2.114}=4.71 \mathrm{p}<0.02$ & $\begin{array}{c}\mathrm{F}_{2.87}=4.95 \\
\mathrm{p}<<0.01\end{array}$ & \\
\hline & Q & NS & $\begin{array}{c}\mathrm{F}_{2.114}=3.99 \\
\mathrm{p}<0.02\end{array}$ & NS & \\
\hline & ZW & None & NS & NS & \\
\hline & total & $\begin{array}{c}F_{2.45}=6.65 \\
p<0.02\end{array}$ & $\begin{array}{c}F_{2.114}=3.67 \\
p<0.05\end{array}$ & $\begin{array}{c}F_{2.87}=4.08 \\
p<0.02\end{array}$ & \\
\hline
\end{tabular}

and the total number of people involved was usually on average two or three times higher (Student's t-test, $\mathrm{t}=4.54$ (58), $\mathrm{t}=$ 3.57 (58) and $t=3.32, \mathrm{p}<0.001$, respectively for June 2014, May 2015 and June 2015) (Table 1). The number of people spending their time in this area was always significantly higher than in OMC (ANOVA, $\mathrm{F}_{2.82}$ $=6.25, \mathrm{p}<0.01, \mathrm{~F}_{2.82}=4.28, \mathrm{p}<0.02, \mathrm{~F}_{2.82}=$ $3.41, \mathrm{p}<0.05$, respectively for June 2014,
May 2015 and June 2015) (Table 1). The number of places with all the distinguished forms of activity, as well as the differences in the frequency of occurrence between areas with different classes of natural values, are presented in Table 2.

While analysing these results, it is worth emphasizing that the smallest differences between the areas, although statistically significant in June 2015 (ANOVA, 
$\left.\mathrm{F}_{2.82}=3.62, \mathrm{p}<0.05\right)$, occurred in the water tourism, intermediate in the case of land tourism (ANOVA, $\mathrm{F}_{2.82}=4.69, \mathrm{p}<0.02$, for June 2014) and by far the largest in the case of grazing livestock, and especially camping and motorized tourism (quads, motorcycles, off-road vehicles) on islands (ANOVA, between $\mathrm{F}_{2.82}=2.79, \mathrm{p}=0.067$, and $\mathrm{F}_{2.82}=6.88, \mathrm{p}<0.001$ ) (Table 2). It should be noted that the number of places with grazing livestock, and especially with the presence of off-road vehicles at $\mathrm{OBC}$, had been increasing with each subsequent census, between June 2014 and June 2015, while the number of camping sites remained more or less constant (Table 2).

\section{Discussion}

Nowadays, it is probably no longer necessary to convince anyone that human activity is increasingly contributing to the degradation of inanimate nature and the disappearance of many species of plants and animals (e.g. review in Pullin 2004). The demographic success of humans is closely linked to aggressive, excessive and unsustainable use of the Earth's natural resources. As a result of the increasing anthropogenic transformation of virtually all terrestrial, wetland and aquatic environments, the number of animal and plant species in the world has been steadily and rapidly decreasing over the last century (Symonides 2014). The Middle Vistula Valley is no exception. The intensive development and use of the valley, the creation of large, complex hydro-technical buildings and the related narrowing of the riverbed, as well as the irreversible destruction of the forests on its banks led to significant impoverishment of valuable plant habitats, and many animal species became extinct or dramatically reduced in numbers (Backiel 1983; Wesołowski 1986; Gacka-Grzesikiewicz 1995; Chylarecki et al. 1995). Over the last twenty years, it has been possible to assess the impact of small and large hydrotechnical buildings, human activity on the riverbed (sandpits, grazing), and the appearance, indirectly related to human activity, of invasive alien mammalian species (the American mink Neovison vison, the Asian racoon dog Nyctereutes procyonoides) on the functioning of key species of the Vistula bird communities (Chylarecki et al. 1995, 1998; Keller et al. 1999; Bukaciński and Bukacińska 1995, 2008, 2015a; Bukaciński, Bukacińska and Buczyński 2011, 2013). The increasingly popular and widespread return of city dwellers to nature has caused another real threat to the Vistula nature in recent years, not to mention the forms of spending free time in this place (Bukaciński and Bukacińska 2001; Angiel and Bukaciński 2015). As the very phenomenon of the mass presence of people in the Vistula valley, although undoubtedly becoming more and more frequent, is relatively new, knowledge about the impact of various forms of tourism on the birds of the river valley is fragmentary and mainly qualitative (Bukaciński and Bukacińska 2001, 2008; Angiel and Bukaciński 2015). The first necessary task to change that was to carry out a quantitative and spatial inventory of all forms of human activity on the most ornithologically valuable fragment of the middle Vistula, between Puławy and the mouth of Pilica (Bukaciński et al. 1994; Bukaciński 2010). The results of the monitoring, taking into account the unique natural value and the need to protect endangered bird species for which the middle Vistula is a key breeding ground in the country, are very worrying. Although the censuses were carried out outside the period of naturally greater tourist activity related to the holiday period or the so-called long weekends, the presence of people in the riverbed was common and increased both in areas less valuable for birds and in places of their key breeding habitats. What is more, in places less frequently inhabited by birds, the presence of fishermen was predominant, while in the key breeding grounds of gulls, terns and plovers, we observed more frequent and more numerous forms of activity that have a greater impact on nature: (1) family campsites with several people, com- 


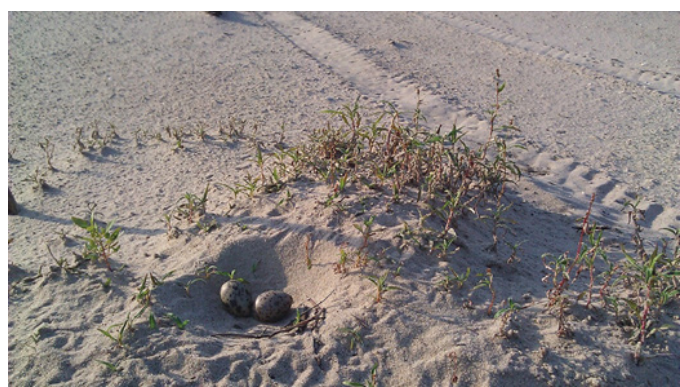

Photo. 1. Traces of a quad near the nest of oystercatcher Haematopus ostralegus (photo: Arkadiusz Buczyński).

bined with campfires, tents and hours of loud behaviour and constant disturbance of animals, and (2) mechanized tourism (quads, motorcycles, off-road vehicles), which, in addition to even greater disturbance of animals, also leads to the physical destruction of breeding habitats, nests with eggs and increased mortality of hatchlings of gulls, terns, plovers and other birds living there (Bukaciński and Bukacińska 2001, 2008, unpublished materials, Photo. 1.). The threat of modern forms of tourism to the living nature of the Vistula Valley is increasing and very serious. Recreation over water is increasingly popular and common, and the number of islands and shoals, which are a preferred breeding ground for the endangered little terns, ringed plovers and mew gulls (Bukaciński and Bukacińska 2015a), used for race and off-road tracks for quads, motorcycles and off-road vehicles is growing exponentially every year (Bukaciński with the team, unpublished materials). We are already observing the withdrawal of the riverbed birds from the places under the greatest pressure, more and more often we are noting the cases of nests and hatchlings being destroyed by vehicles (Bukaciński with the team, unpublished materials).

In the coming years, we plan to investigate the influence of various forms of human activity on habitat selection, breeding behaviour, growth and survival of hatchlings and breeding success of selected species of Charadriiformes (gulls, terns, plovers, oystercatchers Haematopus os- tralegus). In similar studies on other bird species, it was found that the sheer number of people on the breeding grounds had a negative impact on their reproductive ecology (Remacha, Perez-Tri, and Delgado 2011). The negative impact of various forms of tourism on the physiology and breeding behaviour of adult birds is more often observed (stress and its impact on breeding biology, disturbance of selection of habitats, foraging, etc.), as well as the impact on the survival of nests with eggs (heat stress or chilling of eggs, increase in predation rate) and hatchlings (getting lost, death from exhaustion and/ or starvation, increase in predation rate) (e.g. Verhulst, Oosterbeek, and Ens 2001; Bolduc and Guillemette 2003; Finney, Pearce-Higgins, and Yalden 2005; Ellenberg et al. 2006; Yasue and Dearen 2006; Cardoni, Favero, and Isacch 2008; Watson Bolton, and Monaghan 2014; Albano et al. 2015).

The middle Vistula valley is currently one of the few exceptional places in Europe, where fragments of habitats characteristic of large, natural, braided and lowland rivers with a unique complex of riverbed avifauna and riparian forests have been preserved (Tomiałojć and Dyrcz 1993; Chylarecki et al. 1995; Dombrowski et al. 1998). To preserve the natural value of this place for future generations; there is an urgent need for action in two areas: education raising the general ecological awareness of the society and active protection of endangered species of Charadriiformes and conservation of areas of selected parts of the river; protecting the most valuable parts of the river (Bukaciński 2015; Angiel and Bukaciński 2015).

Acknowledgements: They also participated in the collection of materials: Arkadiusz Buczyński, Martyna Drzyzga, Bartosz Jaszewski and Marek Sawicki. Without them, this paper would not have been possible. Thank you very much. We thank the reviewers for their valuable, constructive comments on the earlier version of the manuscript. 


\section{Bibliography}

Albano, Noelia, Francisco Santiago-Quesada, Jose A. Masero, Juan Manuel Sanchez-Guzman, and Erich Möstl. 2015. "Immunoreactive cortisone in droppings reflect stress levels, diet and growth rate in gull-billed tern chicks." General and Comparative Endocrinology 213: 74-80.

Andrejczuk, Wiaczesław. 2007. "Krajobrazy dolin rzecznych." W Doliny rzeczne Przyroda - Krajobraz - Człowiek, red. Urszula Myga-Piątek, 9-27. Sosnowiec: Komisja Krajobrazu Kulturowego Polskiego Towarzystwa Geograficznego.

Angiel, Joanna. 2007. "Postrzeganie rzeki Wisły jako wartości przyrodniczej i kulturowej w aspekcie edukacji geograficznej." W Doliny rzeczne Przyroda - Krajobraz - Człowiek, red. Urszula Myga-Piątek, 245-254. Sosnowiec: Komisja Krajobrazu Kulturowego Polskiego Towarzystwa Geograficznego.

Angiel, Joanna, i Dariusz Bukaciński. 2015. Oblicza Wisty. Przewodnik warszawski dla tropicieli przyrody. Warszawa: Stowarzyszenie Stołeczne Towarszystwo Ochrony Ptaków.

Backiel, Tadeusz. 1983. "Fisheries and fishes of the Vistula River." W Ekologiczne podstawy zagospodarowania Wisty i jej dorzecza, red. Zdzisław Kajak, 511-542. Warszawa: Wydawnictwo Naukowe PWN.

Bolduc, Francois, and Magella Guillemette. 2003. "Human disturbance and nesting success of Common Eiders: interaction between visitors and gulls." Biological Conservation 110: 77-83.

Bukacińska, Monika, i Dariusz Bukaciński. 2004a. "Larus ridibundus (L., 1766) - śmieszka.” W Ptaki (część II). Poradniki ochrony siedlisk i gatunków Natura 2000 - podręcznik metodyczny, T. 7, red. Maciej Gromadzki, 160-165. Warszawa: Ministerstwo Środowiska.

Bukacińska, Monika, i Dariusz Bukaciński. 2004b. "Larus canus (L., 1758) - mewa pospolita.” W Ptaki (część II). Poradniki ochrony siedlisk i gatunków Natura 2000 - podręcznik metodyczny T. 7, red. Maciej Gromadzki, 166-170. Warszawa: Ministerstwo Środowiska.

Bukacińska, Monika, i Dariusz Bukaciński, 2004c. "Sterna hirundo (L., 1758) - rybitwa rzeczna." W Ptaki (część II). Poradniki ochrony siedlisk i gatunków Natura 2000 - podręcznik metodyczny, T. 7, red. Maciej Gromadzki, 186-191. Warszawa: Ministerstwo Środowiska.

Bukaciński, Dariusz. 2010. "Dolina Środkowej Wisły." W: Ostoje ptaków o znaczeniu międzynarodowym $w$ Polsce, red. Tomasz Wilk, Maria Jujka, Jarosław Krogulec, i Przemysław Chylarecki, 297-299. Marki: OTOP.

Bukaciński, Dariusz. 2015. Strategia czynnej ochrony zagrożonej awifauny wysp środkowej Wisty: podręcznik najlepszych praktyk. Marki: OTOP.

Bukaciński, Dariusz, i Monika Bukacińska. 1994. "Czynniki wpływające na zmiany liczebności i rozmieszczenie mew, rybitw i sieweczek na Wiśle Środkowej." Notatki Ornitologiczne 35: 79-97.

Bukaciński, Dariusz, and Monika Bukacińska. 1995. "The factors limiting breeding success in the Black-headed Gull (Larus ridibundus) in different habitat types on the middle course of the Vistula River, Poland." Archive für Hydrobiologie 101, Large Rivers, 9: 221-228.

Bukaciński, Dariusz, i Monika Bukacińska. 2001. "Zagrożenia ptaków gniazdujących na Wiśle Środkowej." W Strategia ochrony fauny na Nizinie Mazowieckiej, red. Henryk Kot, i Andrzej Dombrowski, 117-128. Siedlce: Mazowieckie Towarzystwo Ochrony Fauny.

Bukaciński, Dariusz, and Monika Bukacińska. 2008. "Threatened bird species of the middle Vistula River islands: status, necessity for protection and proposed activities." In Theoretical and applied aspects of modern ecology, edited by Janusz Uchmański, 219-239. Warszawa: Wydawnictwo UKSW.

Bukaciński, Dariusz, i Monika Bukacińska. 2015a. Kluczowe gatunki ptaków siewkowych na środkowej Wiśle: biologia, ekologia, ochrona $i$ występowanie. Monografie. Warszawa: Stowarzyszenie Stołeczne Towarzystwo Ochrony Ptaków.

Bukaciński, Dariusz, i Monika Bukacińska. 2015b. "Rybitwa rzeczna Sterna hirundo." W Monitoring ptaków leggowych. Poradnik metodyczny, red. Przemysław Chylarecki, Arkadiusz Sikora, Zdzisław Cenian, i Tomasz Chodkiewicz, 299-306. Warszawa: GIOŚ. 
Bukaciński, Dariusz, i Monika Bukacińska. 2015c. "Mewa siwa Larus canus." W Monitoring ptaków legowych. Poradnik metodyczny, red. Przemysław Chylarecki, Arkadiusz Sikora, Zdzisław Cenian, i Tomasz Chodkiewicz, 286-292. Warszawa: GIOŚ.

Bukaciński, Dariusz, Jakub Paweł Cygan, Marek Keller, Małgorzata Piotrowska, i Janusz Wójciak. 1994. "Liczebność i rozmieszczenie ptaków wodnych gniazdujących na Wiśle Środkowej - zmiany w latach 1973-1993." Notatki Ornitologiczne 35: 5-47.

Bukaciński, Dariusz, Monika Bukacińska, i Arkadiusz Buczyński. 2011. "Awifauna wodnobłotna środkowej Wisły w okresie lęgowym: wpływ działalności człowieka na rozmieszczenie, liczebność i bogactwo gatunkowe." Studia Ecologiae et Bioethicae 9: 67-86.

Bukaciński, Dariusz, Monika Bukacińska, and Arkadiusz Buczyński. 2013. "The impact of hydrotechnical facilities on island avifauna: a case study of the middle Vistula River." Studia Ecologiae et Bioethicae 11: 93-109.

Bukaciński, Dariusz, Monika Bukacińska, i Piotr Zieliński. 2015. "Śmieszka Chroicocephalus ridibundus." W Monitoring ptaków lęgowych. Poradnik metodyczny, red. Przemysław Chylarecki, Arkadiusz Sikora, Zdzisław Cenian i Tomasz Chodkiewicz, 266-274. Warszawa: GIOŚ.

Cardoni, Daniel Augusto, Marco Favero, and Juan Pablo Isacch. 2008. "Recreational activities affecting the habitat use by birds in Pampa's wetlands, Argentina: implications for waterbird conservation." Biological Conservation 141: 797-806.

Chylarecki, Przemysław, Dariusz Bukaciński, Andrzej Dombrowski, i Wiesław Nowicki. 1995. "Awifauna." W Korytarz ekologiczny doliny Wisty. Stan - funkcjonowanie - zagrożenia, red. Ewa Gacka-Grzesikiewicz, 79-124. Warszawa: IUCN Poland.

Chylarecki, Przemysław, Marek Keller, Piotr Zieliński, i Wiesław Nowicki. 1998. Przyrodnicze podstawy opracowania optymalnej koncepcji zagospodarowania obszaru doliny Wisty na odcinku od ujścia Narwi do stopnia Wtoctawek. Inwentaryzacja awifauny legowej w 1998 r. Warszawa: Ekspertyza dla Instytutu Geografii i Przestrzennego Zagospodarowania PAN.
Chylarecki, Przemysław, i Gerard Sawicki. 2003. Ostoja ptaków Dolina Środkowej Wisty. Warszawa: Akson.

Dombrowski, Andrzej, Sławomir Chmielewski, Dariusz Bukaciński, Mirosław Rzępała, i Andrzej Brzozowski. 1998. "Ornitologiczna ranga największych rzek dorzecza Wisły Srodkowej." Notatki ornitologiczne 39: 61-75.

Ellenberg, Ursula, Thomas Mattern, Philip J. Seddon, and Jorquera Luna Guillermo. 2006. "Physiological and reproductive consequences of human disturbance in Humboldt penguins: the need for species-specific visitor management." Biological Conservation 133: 95-106.

Finney, Suzanne K., James W. Pearce-Higgins, and Derek William Yalden. 2005. "The effect of recreational disturbance on an upland breeding bird, the golden plover Pluvialis apricaria." Biological Conservation 121: 53-63.

Gacka-Grzesikiewicz, Ewa. 1995. Korytarz ekologiczny doliny Wisty: stan, funkcjonowanie, zagrożenia. Warszawa: IUCN Poland.

Imboden, Christoph. 1987. Riverine forests in Europe - status and conservation. Cambridge: International Council of Bird Protection.

Keller, Marek, Dariusz Bukaciński, Małgorzata Piotrowska, i Janusz Wójciak. 1999. Ocena stanu awifauny lęgowej doliny Wisty na odcinku od ujścia Pilicy do ujścia Sanu. Warszawa: Ekspertyza dla Instytutu Geografii i Przestrzennego Zagospodarowania PAN.

Kot, Henryk, Dariusz Bukaciński, Marek Keller, Andrzej Dombrowski, Patryk Rowiński, i Wojciech Błędowski. 2009. Inwentaryzacja ptaków w granicach Obszaru Specjalnej Ochrony Natura 2000 Dolina Środkowej Wisty PLB 140004. Warszawa: Raport dla RDOŚ.

Liro, Anna, Irmina Głowacka, Wojciech Jakubowski, Jacek Kaftan, Aniela Matuszkiewicz, i Jakub Szacki. 1995. Koncepcja krajowej sieci ekologicznej Econet - Polska. Warszawa: Fundacja IUCN Poland.

Łomnicki, Adam. 2010. Wprowadzenie do statystyki dla przyrodników. Warszawa: Wydawnictwo Naukowe PWN.

Pullin, Andrew S. 2004. Biologiczne podstawy ochrony przyrody. Warszawa: Wydawnictwo Naukowe PWN. 
Reichholf, Josef Helmut. 1987. "Composition of bird fauna in riverine forests." In Riverine forests in Europe - status and conservation, edited by Christoph Imboden, 16-21. Cambridge: International Council of Bird Protection.

Remacha, Carolina, Javier Perez-Tris, and Juan Antonio Delgado. 2011. "Reducing visitors' group size increases the number of birds during educational activities: implications for management of nature-based recreation." Journal of Environmental Management 92: 1564-1568.

Sawicki, Gerard. 2003. Ostoja ptaków Ujście Wisty. Warszawa: Wydawnictwo Askon.

Symonides, Ewa. 2014. Ochrona przyrody. Warszawa: Wydawnictwo Uniwersytetu Warszawskiego.

Tomiałojć, Ludwik, i Andrzej Dyrcz. 1993. "Przyrodnicze wartości dużych rzek i ich dolin w Polsce w świetle badań ornitologicznych." W Ochrona przyrody i środowiska $w$ dolinach nizinnych rzek Polskich, red. Ludwik Tomiałojć, 13-37. Kraków: Wydawnictwo Instytutu Ochrony Przyrody PAN.
Verhulst, Simon, Kees Oosterbeek, and Bruno J. Ens. 2001. "Experimental evidence for effects of human disturbance on foraging and parental care in oystercatchers." Biological Conservation 101: 375-380.

Watson, Hannah, Mark Bolton, and Pat Monaghan. 2014. "Out of sight but not out of harm's way: human disturbance reduces reproductive success of a cavity-nesting seabird." Biological Conservation 174: 127-133.

Wesołowski, Tomasz. 1986. "Riverine populations of gulls and terns in Poland and problems of their protection." Var Fagelvarld Suppl. 11: 233-237.

Yasue, Mai, and Philip Dearen. 2006. "The effects of heat stress, predation risk and parental investment on Malaysian plover nest return times following a human disturbance." Biological Conservation 132: 472-480.

Zar, Jerrold H. 1984. Biostatistical analysis. Englewood Cliffs: Prentice-Hall Inc. 
Annex 1. Number of people on the banks and in the Vistula riverbed in June 2014 ( $\mathrm{N}=242)$ : A - between 373 and $415 \mathrm{~km}$ and B - between 415 and $458 \mathrm{~km}$ of the river of the navigation route. The height of the bar represents the total number of people, the shaded part of the bar represents the number of fishermen, the unshaded part of the bar represents the number of other people. Mileage of the river depending on the natural value of a given place is marked without any distinction (valuable areas - in the text described by the OC symbol) in bold (most valuable areas - OBC symbol) or in italic (least valuable areas - OMC symbol). Liczba osób = Number of people.

Liczba osób

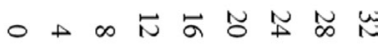

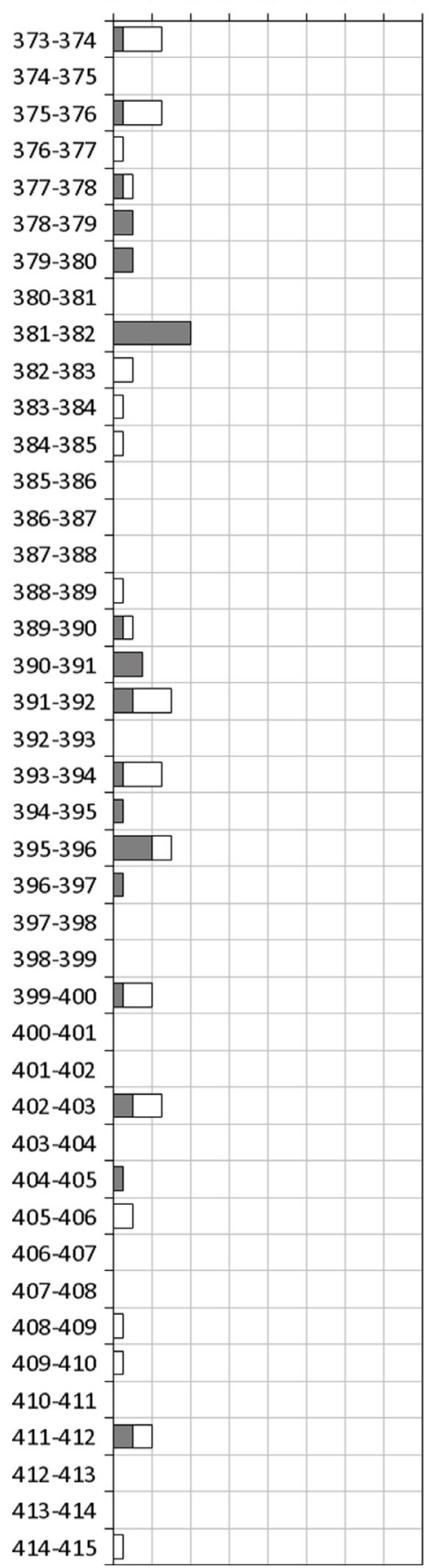

Liczba osób

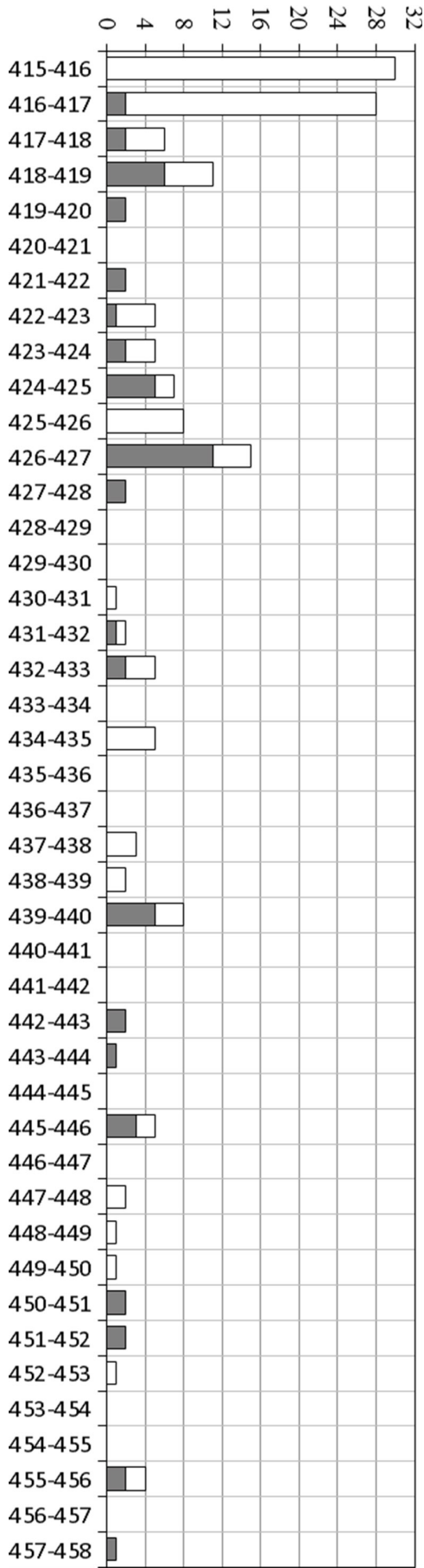


Annex 2. Number of people on the bank and in the Vistula riverbed in May $2015(\mathrm{~N}=122)$.

Other explanations as in Annex 1.

Liczba osób

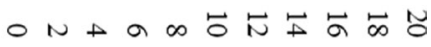

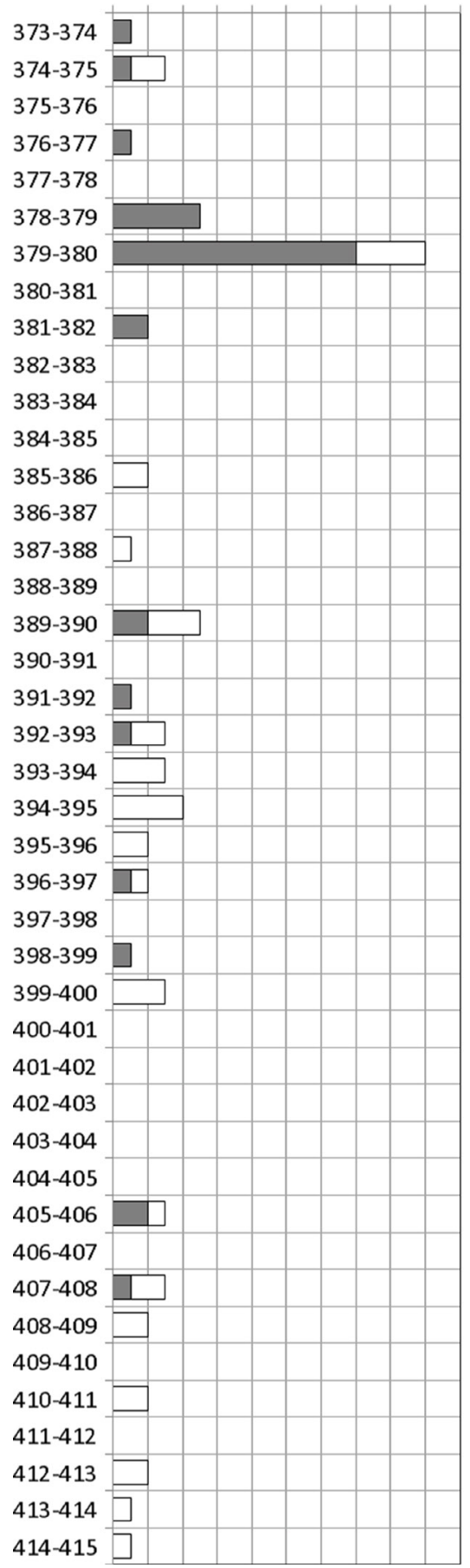

Liczba osób

\begin{tabular}{ll|l|l|l|l|}
\hline & \\
\hline $415-416$ \\
$416-417$
\end{tabular}


Annex 3. Number of people on the banks and in the riverbed of the Vistula River in June 2015 (N=242). Other explanations as in Annex 1.

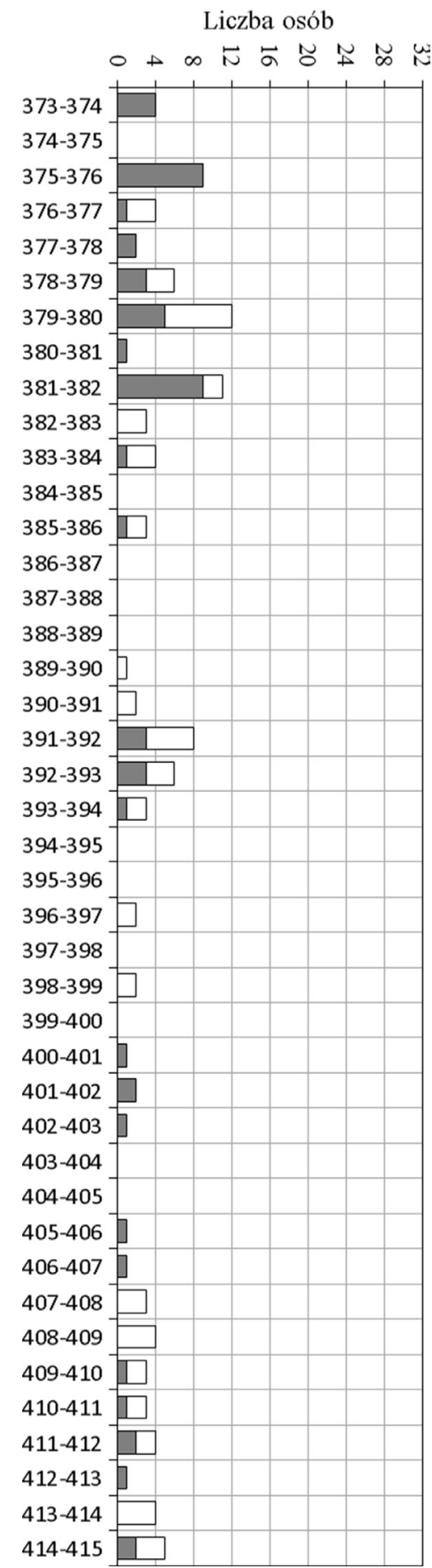

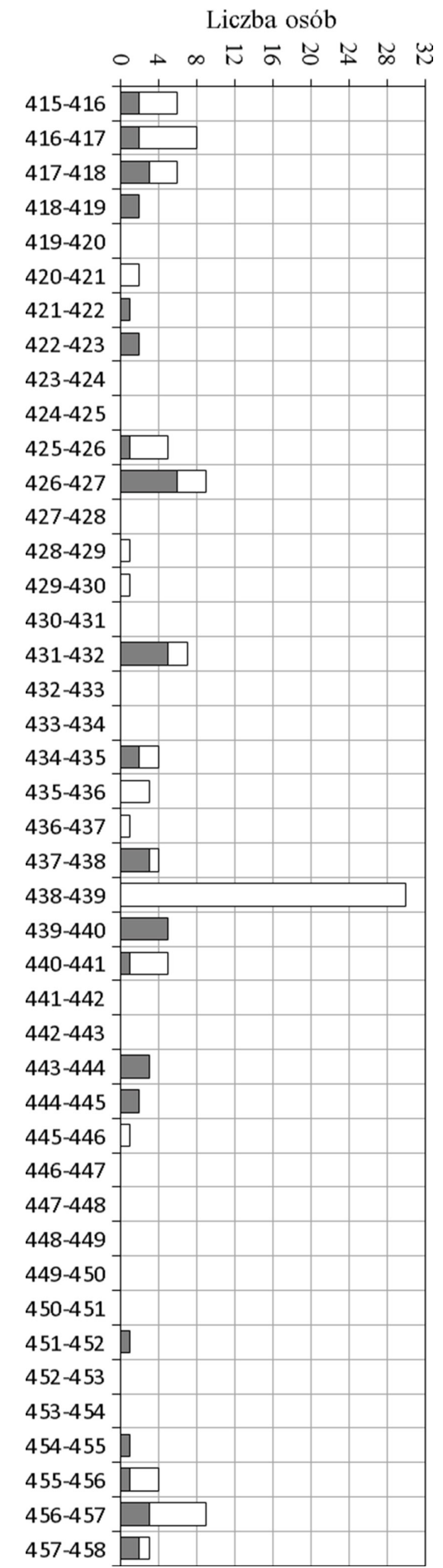


Annex 4. Distribution and frequency of selected human activities on the banks and in the Vistula riverbed between Puławy and the mouth of Pilica ( $\mathrm{km} \mathrm{373-458} \mathrm{of} \mathrm{the} \mathrm{navigation} \mathrm{route)} \mathrm{in} \mathrm{June} \mathrm{2014.} \mathrm{W} \mathrm{-} \mathrm{fishing,} \mathrm{B} \mathrm{-}$ camping (bonfires, tents, campers, etc.), TW - water tourism (all vessels, including windsurfing and jet skis), TL - hiking on islands and peninsulas (people walking, sunbathing, playing, swimming, etc.), Q - off-road vehicles on islands and peninsulas (quads, motorcycles, off-road vehicles, etc.), ZW - grazing animals on islands (cows, horses, sheep, goats). The numerical value represents the number of places with distinguished activity on a given river kilometre. The most valuable sections of the river for birds (in the text - OBC) have been marked in bold, the least valuable sections (in the text - OMC) - in italics, while the remaining sections (called environmentally valuable areas - OC in the text) have been left without distinction.

\begin{tabular}{|c|c|c|c|c|c|c|c|c|}
\hline \multirow{2}{*}{ River mileage } & \multicolumn{6}{|c|}{ Type and frequency of occurrence of a given activity } & \multicolumn{2}{|c|}{ Total number } \\
\hline & W & B & TW & $\mathrm{TL}$ & Q & ZW & $\begin{array}{c}\text { of a given } \\
\text { activity }\end{array}$ & places \\
\hline $373-374$ & 1 & 0 & 1 & 0 & 0 & 0 & 2 & 2 \\
\hline $374-375$ & 0 & 0 & 0 & 0 & 0 & 0 & 0 & 0 \\
\hline $375-376$ & 1 & 1 & 0 & 0 & 0 & 0 & 2 & 2 \\
\hline $376-377$ & 0 & 1 & 0 & 0 & 0 & 0 & 1 & 1 \\
\hline $377-378$ & 0 & 1 & 0 & 0 & 1 & 0 & 2 & 2 \\
\hline $378-379$ & 1 & 0 & 0 & 0 & 0 & 0 & 1 & 1 \\
\hline $379-380$ & 2 & 0 & 0 & 0 & 0 & 0 & 1 & 2 \\
\hline $380-381$ & 0 & 0 & 0 & 0 & 0 & 0 & 0 & 0 \\
\hline $381-382$ & 3 & 0 & 0 & 0 & 0 & 0 & 1 & 3 \\
\hline $382-383$ & 0 & 1 & $\mathbf{0}$ & 1 & 0 & 0 & 2 & 2 \\
\hline $383-384$ & 0 & 1 & $\mathbf{0}$ & 0 & 0 & 1 & 2 & 2 \\
\hline $384-385$ & 0 & 0 & $\mathbf{0}$ & 0 & 0 & 1 & 1 & 1 \\
\hline $385-386$ & 0 & 0 & 0 & 0 & 0 & 0 & 0 & 0 \\
\hline $386-387$ & 0 & 0 & 0 & 0 & 0 & 0 & 0 & 0 \\
\hline $387-388$ & 0 & 0 & 0 & 0 & 0 & 0 & 0 & 0 \\
\hline $388-389$ & 0 & 0 & 0 & 1 & 0 & 0 & 1 & 1 \\
\hline $389-390$ & 1 & 0 & 1 & 0 & 0 & 0 & 2 & 2 \\
\hline $390-391$ & 1 & 0 & 0 & 0 & 0 & 0 & 1 & 1 \\
\hline 391-392 & 1 & 1 & 1 & 1 & 0 & 0 & 4 & 4 \\
\hline $392-393$ & 0 & $\mathbf{0}$ & 0 & 0 & 0 & 0 & 0 & $\mathbf{0}$ \\
\hline $393-394$ & 1 & 0 & 1 & 1 & 0 & $\mathbf{0}$ & 3 & 3 \\
\hline 394-395 & 0 & $\mathbf{0}$ & $\mathbf{0}$ & 0 & 0 & $\mathbf{0}$ & $\mathbf{0}$ & $\mathbf{0}$ \\
\hline $395-396$ & 2 & 0 & 1 & 1 & 0 & 0 & 3 & 4 \\
\hline $396-397$ & 1 & 0 & 0 & 0 & 0 & 0 & 1 & 1 \\
\hline $397-398$ & 0 & 0 & 0 & 0 & 0 & 0 & 0 & 0 \\
\hline 398-399 & 0 & 0 & 0 & 0 & 0 & 0 & 0 & 0 \\
\hline $399-400$ & 1 & 0 & 0 & 1 & 0 & 0 & 2 & 2 \\
\hline $400-401$ & 0 & 0 & 0 & 0 & 0 & 0 & 0 & 0 \\
\hline 401-402 & 0 & 0 & 0 & 0 & 0 & 0 & 0 & 0 \\
\hline $402-403$ & 1 & 1 & 1 & 0 & 0 & $\mathbf{0}$ & 3 & 3 \\
\hline $403-404$ & 0 & 0 & 0 & 0 & 0 & $\mathbf{0}$ & $\mathbf{0}$ & 0 \\
\hline 404-405 & 1 & 0 & 0 & 0 & 0 & 0 & 1 & 1 \\
\hline $405-406$ & 0 & 1 & 1 & 0 & 0 & 0 & 2 & 2 \\
\hline $406-407$ & 0 & 0 & 0 & 0 & 0 & 0 & 0 & 0 \\
\hline $407-408$ & 0 & 0 & 0 & 0 & 0 & 0 & 0 & 0 \\
\hline $408-409$ & 0 & 1 & 0 & 0 & 0 & 0 & 1 & 1 \\
\hline $409-410$ & 0 & 1 & 0 & 0 & 0 & 0 & 1 & 1 \\
\hline
\end{tabular}




\begin{tabular}{|c|c|c|c|c|c|c|c|c|}
\hline $410-411$ & 0 & 0 & 0 & 0 & 0 & 0 & 0 & 0 \\
\hline 411-412 & 1 & 0 & 1 & 1 & 0 & 1 & 3 & 4 \\
\hline $412-413$ & 0 & 0 & 0 & 0 & 0 & 1 & 1 & 1 \\
\hline $413-414$ & 0 & 0 & 0 & 0 & 0 & 0 & $\mathbf{0}$ & 0 \\
\hline 414-415 & 0 & 0 & 0 & 0 & 1 & 0 & 1 & 1 \\
\hline $415-416$ & 0 & 5 & 2 & 8 & 2 & 0 & 4 & 17 \\
\hline $416-417$ & 1 & 1 & 1 & 4 & 0 & 0 & 4 & 7 \\
\hline $417-418$ & 1 & 1 & 1 & 1 & 0 & 0 & 4 & 4 \\
\hline 418-419 & 1 & 0 & 0 & 1 & 0 & 0 & 2 & 2 \\
\hline $419-420$ & 1 & 0 & 0 & 0 & 0 & 0 & 1 & 1 \\
\hline $420-421$ & 0 & 0 & 0 & 0 & 0 & 0 & 0 & 0 \\
\hline $421-422$ & 1 & 0 & 0 & 0 & 0 & 0 & 1 & 1 \\
\hline $422-423$ & 1 & 1 & 0 & 1 & 0 & 0 & 3 & 3 \\
\hline $423-424$ & 1 & 1 & 0 & 1 & 0 & 0 & 3 & 3 \\
\hline $424-425$ & 2 & 1 & 0 & 0 & 0 & 0 & 2 & 3 \\
\hline $425-426$ & 0 & 0 & 0 & 1 & 0 & 0 & 1 & 1 \\
\hline $426-427$ & 3 & 1 & 1 & 1 & 0 & 0 & 4 & 6 \\
\hline $427-428$ & 1 & 0 & 0 & 0 & 0 & 0 & 1 & 1 \\
\hline $428-429$ & 0 & 0 & 0 & 0 & 0 & 0 & 0 & 0 \\
\hline $429-430$ & 0 & 0 & 0 & 0 & 0 & 0 & 0 & 0 \\
\hline $430-431$ & 0 & 0 & 1 & 0 & 0 & 1 & 2 & 2 \\
\hline $431-432$ & 1 & 0 & 0 & 1 & 0 & 2 & 3 & 4 \\
\hline $432-433$ & 2 & 0 & 2 & 0 & 0 & 1 & 3 & 5 \\
\hline $433-434$ & 0 & 0 & 0 & 0 & 0 & 0 & 0 & 0 \\
\hline $434-435$ & 0 & 0 & 0 & 2 & 0 & 0 & 1 & 2 \\
\hline $435-436$ & 0 & 0 & 0 & 0 & 0 & 0 & 0 & 0 \\
\hline $436-437$ & 0 & 0 & 0 & 0 & 0 & 0 & 0 & 0 \\
\hline $437-438$ & 0 & 1 & 0 & 1 & 0 & 0 & 2 & 2 \\
\hline $438-439$ & 0 & 0 & 1 & 1 & 0 & 0 & 2 & 2 \\
\hline $439-440$ & 1 & 0 & 1 & 1 & 1 & 0 & 4 & 4 \\
\hline $440-441$ & 0 & 0 & 0 & 0 & 0 & 0 & 0 & 0 \\
\hline 441-442 & 0 & 0 & 0 & 0 & 0 & 0 & 0 & 0 \\
\hline $442-443$ & 1 & 0 & 0 & 0 & 0 & 0 & 1 & 1 \\
\hline $443-444$ & 1 & 0 & 0 & 0 & 0 & 0 & 1 & 1 \\
\hline 444-445 & 0 & 0 & 0 & 0 & 0 & 0 & 0 & 0 \\
\hline $445-446$ & 1 & 1 & 0 & 0 & 0 & 0 & 2 & 2 \\
\hline $446-447$ & 0 & 0 & 0 & 0 & 0 & 0 & 0 & 0 \\
\hline $447-448$ & 0 & 1 & 0 & 0 & 0 & 0 & 1 & 1 \\
\hline $448-449$ & 0 & 0 & 1 & 0 & 0 & 0 & 1 & 1 \\
\hline $449-450$ & 0 & 0 & 1 & 0 & 0 & 0 & 1 & 1 \\
\hline $450-451$ & 1 & 0 & 0 & 0 & 0 & 0 & 1 & 1 \\
\hline $451-452$ & 1 & 0 & 0 & 0 & 0 & 0 & 1 & 1 \\
\hline $452-453$ & 0 & 0 & 1 & 0 & 0 & 0 & 1 & 1 \\
\hline $453-454$ & 0 & 0 & 0 & 0 & 0 & 0 & 0 & 0 \\
\hline $454-455$ & 0 & 0 & 0 & 0 & 0 & 0 & 0 & 0 \\
\hline $455-456$ & 1 & 1 & 0 & 0 & 0 & 0 & 2 & 2 \\
\hline $456-457$ & 0 & 0 & 0 & 0 & 0 & 0 & 0 & 0 \\
\hline $457-458$ & 1 & 0 & 0 & 0 & 0 & 0 & 1 & 1 \\
\hline total & 43 & 25 & 21 & 31 & 5 & 8 & $\begin{array}{c}\text { not } \\
\text { applicable }\end{array}$ & 133 \\
\hline
\end{tabular}


Annex 5. Distribution and frequency of selected human activities on the banks and in the Vistula riverbed between Puławy and the mouth of Pilica (km 373-458 of the navigation route) in May 2015.

Other explanations as in Annexes 1 and 4.

\begin{tabular}{|c|c|c|c|c|c|c|c|c|}
\hline \multirow[b]{2}{*}{ River mileage } & \multicolumn{6}{|c|}{ Type and frequency of occurrence of a given activity } & \multicolumn{2}{|c|}{ Total number } \\
\hline & W & B & TW & $\mathrm{TL}$ & Q & ZW & $\begin{array}{c}\text { of a given } \\
\text { activity }\end{array}$ & places \\
\hline $373-374$ & 1 & 0 & 0 & 0 & 0 & 0 & 1 & 1 \\
\hline $374-375$ & 1 & 1 & 0 & 0 & 0 & 0 & 2 & 2 \\
\hline $375-376$ & 0 & 0 & 0 & 0 & 0 & 0 & 0 & 0 \\
\hline $376-377$ & 1 & 0 & 0 & 0 & 0 & 0 & 1 & 1 \\
\hline $377-378$ & 0 & 0 & 0 & 0 & 0 & 0 & 0 & 0 \\
\hline $378-379$ & 1 & 0 & 0 & 0 & 0 & 0 & 1 & 1 \\
\hline $379-380$ & 1 & 0 & 0 & 1 & 1 & 0 & 3 & 3 \\
\hline $380-381$ & 0 & 0 & 0 & 0 & 0 & 0 & 0 & 0 \\
\hline $381-382$ & 1 & 0 & 0 & 0 & 0 & 0 & 1 & 1 \\
\hline $382-383$ & 0 & 0 & 0 & 0 & 0 & 0 & 0 & 0 \\
\hline $383-384$ & 0 & 0 & $\mathbf{0}$ & 0 & 0 & 1 & 1 & 1 \\
\hline 384-385 & 0 & 0 & $\mathbf{0}$ & 0 & 0 & 1 & 1 & 1 \\
\hline $385-386$ & 0 & 0 & $\mathbf{0}$ & 0 & 1 & $\mathbf{0}$ & 1 & 1 \\
\hline $386-387$ & 0 & 0 & 0 & 0 & 0 & 0 & 0 & 0 \\
\hline $387-388$ & 0 & 0 & 0 & 0 & 1 & 0 & 1 & 1 \\
\hline $388-389$ & 0 & 0 & 0 & 0 & 0 & 0 & 0 & 0 \\
\hline $389-390$ & 1 & 0 & 0 & 1 & 0 & 0 & 2 & 2 \\
\hline $390-391$ & 0 & 0 & 0 & 0 & 0 & 0 & 0 & 0 \\
\hline 391-392 & 1 & 0 & 0 & 0 & 0 & 0 & 1 & 1 \\
\hline $392-393$ & 1 & 0 & 1 & 0 & 0 & 0 & 2 & 2 \\
\hline $393-394$ & 0 & 1 & 1 & 0 & 0 & 0 & 2 & 2 \\
\hline 394-395 & 0 & 1 & 1 & 0 & 0 & 0 & 2 & 2 \\
\hline $395-396$ & 0 & 1 & 1 & 0 & 0 & 0 & 2 & 2 \\
\hline $396-397$ & 1 & 0 & 1 & 0 & 0 & 0 & 2 & 2 \\
\hline $397-398$ & 0 & 0 & 0 & 0 & 0 & 0 & 0 & 0 \\
\hline 398-399 & 1 & 0 & 0 & 0 & 0 & 0 & 1 & 1 \\
\hline $399-400$ & 0 & 1 & 0 & 0 & 0 & 0 & 1 & 1 \\
\hline $400-401$ & 0 & 0 & 0 & 0 & 0 & 0 & 0 & 0 \\
\hline $401-402$ & 0 & 0 & 0 & 0 & 0 & 0 & 0 & 0 \\
\hline $402-403$ & 0 & 0 & 0 & 0 & 0 & 0 & 0 & 0 \\
\hline $403-404$ & 0 & 0 & 0 & 0 & 0 & 0 & 0 & 0 \\
\hline 404-405 & 0 & 0 & 0 & 0 & 0 & 0 & 0 & 0 \\
\hline $405-406$ & 1 & 1 & 0 & 0 & 0 & 0 & 2 & 2 \\
\hline $406-407$ & 0 & 0 & 0 & 0 & 0 & 0 & 0 & 0 \\
\hline $407-408$ & 1 & 1 & 0 & 0 & 0 & 0 & 2 & 2 \\
\hline $408-409$ & 0 & 0 & 0 & 1 & 0 & 0 & 1 & 1 \\
\hline $409-410$ & 0 & 0 & 0 & 0 & 1 & 0 & 1 & 1 \\
\hline $410-411$ & 0 & 1 & 0 & 1 & 1 & 0 & 3 & 3 \\
\hline 411-412 & 0 & 0 & 0 & 0 & 0 & 0 & 0 & 0 \\
\hline $412-413$ & 0 & 0 & 0 & 1 & 0 & 1 & 2 & 2 \\
\hline $413-414$ & 0 & 0 & 1 & 0 & 0 & 0 & 1 & 1 \\
\hline 414-415 & 0 & 0 & 0 & 0 & 1 & 0 & 1 & 1 \\
\hline $415-416$ & 1 & 1 & 0 & 0 & 1 & 0 & 3 & 3 \\
\hline
\end{tabular}




\begin{tabular}{|c|c|c|c|c|c|c|c|c|}
\hline $416-417$ & 2 & 2 & 0 & 0 & 0 & $\mathbf{0}$ & 2 & 4 \\
\hline $417-418$ & 0 & 1 & 0 & 0 & 0 & 1 & 2 & 2 \\
\hline $418-419$ & 1 & 0 & 0 & 0 & 1 & 1 & 3 & 3 \\
\hline $419-420$ & 0 & 0 & 0 & 0 & 0 & 0 & 0 & 0 \\
\hline $420-421$ & 1 & 0 & 0 & 0 & 0 & 0 & 1 & 1 \\
\hline $421-422$ & 0 & 0 & 0 & 0 & 0 & 0 & 0 & 0 \\
\hline $422-423$ & 0 & 0 & 0 & 0 & 0 & 0 & 0 & 0 \\
\hline $423-424$ & 1 & 0 & 0 & 0 & 0 & 0 & 1 & 1 \\
\hline $424-425$ & 0 & 0 & 0 & 0 & 0 & 0 & 0 & 0 \\
\hline $425-426$ & 0 & 0 & 0 & 0 & 0 & 0 & 0 & 0 \\
\hline $426-427$ & 0 & 0 & 1 & 0 & 0 & 0 & 1 & 1 \\
\hline $427-428$ & 0 & 0 & 0 & 0 & 0 & 0 & 0 & 0 \\
\hline $428-429$ & 0 & 0 & 0 & 0 & 0 & 0 & 0 & 0 \\
\hline $429-430$ & 0 & 0 & 0 & 0 & 0 & 0 & 0 & 0 \\
\hline $430-431$ & 0 & 0 & 0 & 0 & 0 & 0 & 0 & 0 \\
\hline $431-432$ & 0 & 0 & 0 & 0 & 0 & 1 & 1 & 1 \\
\hline $432-433$ & 0 & 0 & 0 & 0 & 0 & 1 & 1 & 1 \\
\hline $433-434$ & 0 & 0 & 0 & 0 & 0 & 0 & 0 & 0 \\
\hline $434-435$ & 0 & 0 & 0 & 0 & 0 & 0 & 0 & 0 \\
\hline $435-436$ & 0 & 0 & 0 & 0 & 0 & 0 & 0 & 0 \\
\hline $436-437$ & 0 & 0 & 0 & 0 & 0 & 0 & 0 & 0 \\
\hline $437-438$ & 1 & 0 & 0 & 1 & 0 & 0 & 2 & 2 \\
\hline $438-439$ & 0 & 0 & 0 & 0 & 0 & 0 & 0 & 0 \\
\hline $439-440$ & 1 & 0 & 0 & 0 & 0 & 0 & 1 & 1 \\
\hline $440-441$ & 1 & 0 & 0 & 0 & 0 & $\mathbf{0}$ & 1 & 1 \\
\hline 441-442 & 1 & 0 & 0 & 0 & 0 & 0 & 1 & 1 \\
\hline $442-443$ & 0 & 0 & 0 & 0 & 0 & 0 & $\mathbf{0}$ & 0 \\
\hline $443-444$ & 0 & 0 & 0 & 0 & 0 & 0 & 0 & 0 \\
\hline $444-445$ & 1 & 0 & 0 & 0 & 0 & 0 & 1 & 1 \\
\hline $445-446$ & 0 & 1 & 1 & 0 & 0 & 0 & 2 & 2 \\
\hline $446-447$ & 0 & 0 & 0 & 0 & 0 & 0 & 0 & 0 \\
\hline $447-448$ & 0 & 0 & 0 & 0 & 0 & 0 & 0 & 0 \\
\hline $448-449$ & 0 & 0 & 0 & 0 & 0 & 0 & 0 & 0 \\
\hline $449-450$ & 0 & 0 & 0 & 0 & 0 & 0 & 0 & 0 \\
\hline $450-451$ & 1 & 1 & 0 & 0 & 0 & 0 & 2 & 2 \\
\hline $451-452$ & 0 & 0 & 1 & 0 & 0 & 0 & 1 & 1 \\
\hline $452-453$ & 0 & 0 & 1 & 0 & 0 & 0 & 1 & 1 \\
\hline $453-454$ & 0 & 1 & 0 & 0 & 0 & 0 & 1 & 1 \\
\hline $454-455$ & 0 & 0 & 0 & 1 & 0 & $\mathbf{0}$ & 1 & 1 \\
\hline $455-456$ & 0 & 0 & 1 & 1 & 0 & 0 & 2 & 2 \\
\hline $456-457$ & 1 & 1 & 0 & 0 & 0 & 0 & 2 & 2 \\
\hline $457-458$ & 0 & 0 & 1 & 1 & 0 & 0 & 2 & 2 \\
\hline total & 25 & 16 & 11 & 8 & 8 & 7 & $\begin{array}{c}\text { not } \\
\text { applicable }\end{array}$ & 78 \\
\hline
\end{tabular}


Annex 6. Distribution and frequency of selected human activities on the banks and in the Vistula riverbed between Puławy and the mouth of Pilica (km 373-458 of the navigation route) in June 2015.

Other explanations as in Annexes 1 and 4.

\begin{tabular}{|c|c|c|c|c|c|c|c|c|}
\hline \multirow[b]{2}{*}{ River mileage } & \multicolumn{6}{|c|}{ Type and frequency of occurrence of a given activity } & \multicolumn{2}{|c|}{ Total number } \\
\hline & W & B & TW & $\mathrm{TL}$ & Q & ZW & $\begin{array}{c}\text { of a given } \\
\text { activity }\end{array}$ & places \\
\hline $373-374$ & 2 & 0 & 0 & 0 & 0 & 0 & 1 & 2 \\
\hline $374-375$ & 0 & 0 & 0 & 0 & 0 & 0 & 0 & 0 \\
\hline $375-376$ & 2 & 0 & 0 & 0 & 0 & 0 & 1 & 2 \\
\hline $376-377$ & 1 & 0 & 0 & 0 & 0 & 0 & 1 & 1 \\
\hline $377-378$ & 0 & 1 & 0 & 0 & 0 & 0 & 1 & 1 \\
\hline $378-379$ & 2 & 0 & 0 & 0 & 0 & 0 & 1 & 2 \\
\hline $379-380$ & 2 & 0 & 0 & 2 & 0 & 0 & 2 & 4 \\
\hline $380-381$ & 1 & 0 & 0 & 0 & 0 & 0 & 1 & 1 \\
\hline $381-382$ & 2 & 1 & 0 & 0 & 0 & 0 & 2 & 3 \\
\hline $382-383$ & 0 & 1 & 0 & 0 & 0 & 0 & 1 & 1 \\
\hline $383-384$ & 1 & 2 & $\mathbf{0}$ & 0 & 0 & 1 & 3 & 4 \\
\hline $384-385$ & 0 & 0 & 0 & $\mathbf{0}$ & 0 & 1 & 1 & 1 \\
\hline $385-386$ & 1 & 1 & 0 & 0 & 0 & 0 & 2 & 2 \\
\hline $386-387$ & 0 & 0 & 0 & 0 & 0 & 0 & 0 & 0 \\
\hline $387-388$ & 0 & 0 & 0 & 0 & 0 & 0 & 0 & 0 \\
\hline $388-389$ & 0 & 0 & 0 & 0 & 0 & 0 & 0 & 0 \\
\hline $389-390$ & 0 & 1 & 0 & 0 & 0 & 0 & 1 & 1 \\
\hline $390-391$ & 0 & 0 & 1 & 2 & 0 & 0 & 2 & 3 \\
\hline 391-392 & 3 & 1 & 1 & 2 & 0 & 0 & 4 & 7 \\
\hline $392-393$ & 1 & 0 & 1 & 1 & 0 & $\mathbf{0}$ & 3 & 3 \\
\hline $393-394$ & 1 & 0 & 1 & $\mathbf{0}$ & 0 & $\mathbf{0}$ & 2 & 2 \\
\hline 394-395 & 0 & 0 & 0 & 0 & 0 & 0 & 0 & 0 \\
\hline $395-396$ & 0 & 0 & 0 & 0 & 0 & 0 & 0 & 0 \\
\hline 396-397 & 0 & 0 & 0 & 1 & 0 & 0 & 1 & 1 \\
\hline $397-398$ & 0 & 0 & 0 & 0 & 0 & 0 & 0 & 0 \\
\hline $398-399$ & 0 & 0 & 0 & 1 & 0 & 0 & 1 & 1 \\
\hline $399-400$ & 0 & 0 & 0 & 0 & 0 & 0 & 0 & 0 \\
\hline $400-401$ & 1 & 0 & 0 & 0 & 0 & 0 & 1 & 1 \\
\hline $401-402$ & 1 & 0 & 0 & 0 & 0 & $\mathbf{0}$ & 1 & 1 \\
\hline $402-403$ & 1 & 0 & 0 & 0 & 0 & 0 & 1 & 1 \\
\hline $403-404$ & 0 & 0 & 0 & 0 & 0 & 0 & 0 & 0 \\
\hline 404-405 & 0 & 0 & 0 & 0 & 0 & 0 & 0 & 0 \\
\hline $405-406$ & 1 & 0 & 0 & 0 & 0 & 0 & 1 & 1 \\
\hline $406-407$ & 1 & 0 & 0 & 0 & 0 & 0 & 1 & 1 \\
\hline $407-408$ & 0 & 1 & 0 & 1 & 1 & 0 & 3 & 3 \\
\hline $408-409$ & 0 & 1 & 0 & 1 & 1 & 0 & 3 & 3 \\
\hline $409-410$ & 1 & 0 & 0 & 1 & 1 & 0 & 3 & 3 \\
\hline $410-411$ & 1 & 0 & 0 & 0 & 1 & 2 & 3 & 4 \\
\hline 411-412 & 2 & 1 & 0 & 1 & 0 & 1 & 4 & 5 \\
\hline $412-413$ & 1 & 0 & 0 & 0 & 0 & $\mathbf{0}$ & 1 & 1 \\
\hline $413-414$ & 0 & 0 & 0 & 1 & 0 & 0 & 1 & 1 \\
\hline 414-415 & 2 & 0 & 0 & 2 & 1 & 0 & 3 & 5 \\
\hline $415-416$ & 2 & 0 & 0 & 1 & 2 & $\mathbf{0}$ & 3 & 5 \\
\hline
\end{tabular}




\begin{tabular}{|c|c|c|c|c|c|c|c|c|}
\hline $416-417$ & 2 & 1 & 0 & 2 & 1 & 1 & 5 & 7 \\
\hline $417-418$ & 3 & 1 & 0 & 0 & 1 & 1 & 4 & 6 \\
\hline $418-419$ & 2 & 0 & 0 & 0 & 0 & 1 & 2 & 3 \\
\hline $419-420$ & 0 & 0 & 0 & 0 & 0 & 0 & 0 & 0 \\
\hline $420-421$ & 0 & 1 & 0 & 0 & 0 & 0 & 1 & 1 \\
\hline $421-422$ & 1 & 0 & 0 & 0 & 0 & 0 & 1 & 1 \\
\hline $422-423$ & 1 & 0 & 0 & 0 & 0 & 0 & 1 & 1 \\
\hline $423-424$ & 0 & 0 & 0 & 0 & 0 & 0 & 0 & 0 \\
\hline $424-425$ & 0 & 0 & 0 & 0 & 0 & 0 & 0 & 0 \\
\hline $425-426$ & 1 & 0 & 0 & 1 & 0 & 0 & 2 & 2 \\
\hline $426-427$ & 2 & 1 & 0 & 1 & 0 & 0 & 3 & 4 \\
\hline $427-428$ & 0 & 0 & 0 & 0 & 0 & 0 & 0 & 0 \\
\hline $428-429$ & 0 & 0 & 0 & 0 & 1 & 0 & 1 & 1 \\
\hline $429-430$ & 0 & 0 & 0 & 0 & 1 & 0 & 1 & 1 \\
\hline $430-431$ & 0 & 0 & 0 & 0 & 0 & 0 & 0 & 0 \\
\hline $431-432$ & 2 & 0 & 0 & 1 & 1 & 1 & 4 & 5 \\
\hline $432-433$ & 0 & 0 & 0 & 0 & 0 & 1 & 1 & 1 \\
\hline $433-434$ & 0 & 0 & 0 & 0 & 0 & 1 & 1 & 1 \\
\hline $434-435$ & 1 & 1 & 0 & 0 & 0 & 0 & 2 & 2 \\
\hline $435-436$ & 0 & 1 & 0 & 0 & 0 & 0 & 1 & 1 \\
\hline $436-437$ & 0 & 1 & 0 & 0 & 0 & 0 & 1 & 1 \\
\hline $437-438$ & 1 & 0 & 1 & 0 & 0 & 0 & 2 & 2 \\
\hline $438-439$ & 0 & 1 & 0 & 0 & 0 & 0 & 1 & 1 \\
\hline $439-440$ & 2 & 0 & 1 & 0 & 0 & 0 & 2 & 3 \\
\hline $440-441$ & 1 & 1 & 0 & 0 & 0 & 0 & 2 & 2 \\
\hline 441-442 & 0 & 0 & 0 & 0 & 0 & 0 & 0 & 0 \\
\hline $442-443$ & 0 & 0 & 0 & 0 & 0 & 0 & 0 & 0 \\
\hline $443-444$ & 1 & 0 & 0 & 0 & 0 & 0 & 1 & 1 \\
\hline $444-445$ & 1 & 0 & 0 & 0 & 0 & 0 & 1 & 1 \\
\hline $445-446$ & 0 & 0 & 0 & 1 & 0 & 0 & 1 & 1 \\
\hline $446-447$ & 0 & 0 & 0 & 0 & 0 & 0 & 0 & 0 \\
\hline $447-448$ & 0 & 0 & 0 & 0 & 0 & 0 & 0 & 0 \\
\hline $448-449$ & 0 & 0 & 0 & 0 & 0 & 0 & 0 & 0 \\
\hline $449-450$ & 0 & 0 & 0 & 0 & 0 & 0 & 0 & 0 \\
\hline $450-451$ & 0 & 0 & 0 & 0 & 0 & 0 & 0 & 0 \\
\hline $451-452$ & 1 & 0 & 0 & 0 & 0 & 0 & 1 & 1 \\
\hline $452-453$ & 0 & 0 & 0 & 0 & 0 & 0 & 0 & 0 \\
\hline $453-454$ & 0 & 1 & 0 & 0 & 0 & 0 & 1 & 1 \\
\hline 454-455 & 1 & 0 & 0 & 0 & 0 & 0 & 1 & 1 \\
\hline $455-456$ & 1 & 1 & 1 & 0 & 0 & 0 & 3 & 3 \\
\hline $456-457$ & 2 & 1 & 2 & 1 & 0 & 0 & 4 & 6 \\
\hline $457-458$ & 1 & 0 & 1 & 0 & 0 & 0 & 2 & 2 \\
\hline total & 60 & 23 & 10 & 24 & 12 & 11 & $\begin{array}{c}\text { not } \\
\text { applicable }\end{array}$ & 140 \\
\hline
\end{tabular}

